\title{
Beban Ganda: Kerentanan Perempuan pada Keluarga Miskin
}

\author{
Krisna Yuni Chandra, Fatmariza \\ Prodi Pendidikan Pancasila dan Kewarganegaraan \\ FIS Universitas Negeri Padang \\ E-mail: krisnayunichandra98@gmail.com
}

\section{ABSTRAK}

Beban ganda seringkali menimbulkan kerentanan dan ketidakadilan bagi perempuan, terutama pada keluarga miskin dan mereka yang bekerja sebagai buruh. Artikel ini bertujuan untuk menggambarkan beban ganda perempuan keluarga miskin yang bekerja sebagai buruh pada peternakan ayam. Jenis penelitian ini ialah kualitatif dengan metode deskriptif. Purposive sampling sebagai teknik dalam penentuan informan penelitian. Data dikumpulkan melalui observasi, wawancara, dan dokumentasi. Teknik analisis data menggunakan teknik Miles dan Hurben (1984) dengan tahapan reduksi data, penyajian data, dan verfikasi data. Hasil penelitian menunjukkan beban ganda perempuan buruh tidak hanya berkaitan dengan beban kerja fisik dalam mengurus rumah dan bekerja sebagai buruh, tetapi juga beban psikologis berupa cemoohan karena dianggap tidak mampu melakukan pekerjaan rumah tangga dengan baik. Meskipun buruh perempuan mampu membantu memenuhi kebutuhan ekonomi keluarganya, namun mereka harus menanggung beban pekerjaan yang berat sebagai buruh peternakan ayam, yang mengeluhkan lelah dan pegal-pegal akibat pekerjaannya. Lalu lingkungan pekerjaan (peternakan ayam) yang kurang nyaman bagi mereka, yaitu bau yang kurang enak di peternakan tersebut. Cemoohan juga mereka terima akibat beban ganda yang mereka alami. Waktu untuk berkumpul dengan keluarga pun menjadi berkurang, karena waktu mereka dihabiskan di tempat bekerja. Untuk menghadapi beban ganda yang mereka alami, perempuan buruh membagi waktu nya untuk melakukan semua pekerjaa yang harus mereka kerjakan. Serta menumbuhkan semangat kerja agar tetap mampu memenuhi kebutuhan keluarga.

Kata Kunci: beban ganda, perempuan buruh, peternakan ayam

\section{ABSTRACT}

The double burden often creates vulnerability and injustice for women, especially in poor families and those who work as laborers. This article aims to describe the double burden of women from poor families who work as laborers in chicken farms. This type of research is qualitative with descriptive methods. Purposive sampling as a technique in determining research informants. Data were collected through observation, interviews, and documentation. The data analysis technique used the technique of Miles and Hurben (1984) 
with the stages of data reduction, data presentation, and data verification. The results showed that the double burden of women laborers was not only related to the physical workload in managing the house and working as a laborer, but also the psychological burden in the form of ridicule because they were considered unable to do household chores well. Even though female workers are able to help meet the economic needs of their families, they have to bear the heavy workload as chicken farm workers, who complain about being tired and achy due to their work. Then the working environment (chicken farms) is less comfortable for them, namely the unpleasant smell at the farm. They also received ridicule due to the double burden they experienced. Time to gather with family is reduced, because their time is spent at work. To face the double burden they experience, working women divide their time to do all the work they have to do. As well as fostering morale so that you can still meet family needs.

Keywords: Double burden, Labor women, Chicken farms

(c) (7) (?) This work is licensed under the Creative Commons Attribution-ShareAlike 4.0 International License. EY SA (2020 by author. 


\section{PENDAHULUAN}

Kemiskinan merupakan permasalahan yang dihadapi oleh negara berkembang, tak terkecuali Indonesia. Badan Pusat Statistik mencatat pada Maret 2019 penduduk miskin di Indonesia mencapai 25,14 juta jiwa atau 9,41 persen dari total jumlah penduduk Indonesia. 15,15 juta jiwa diantaranya adalah penduduk miskin di daerah pedesaan, dan 9,99 juta jiwa di daerah perkotaan (www.badan-pusat-statistik.go.id). Data tersebut menunjukan kemiskinan di daerah pedesaan lebih besar dibandingkan daerah perkotaan. Sehingga ini harus diminimalisir khususnya di daerah pedesaan. Sejalan dengan pendapat Cica, Sartika, dkk (2016:106) kenyataan menunjukan bahwa sebagian besar penduduk miskin bermukim di wilayah pedesaan, maka pembangunan pedesaan sebagai bagian dari pembangunan nasional harus mendapat prioritas utama.

Kemiskinan yang terjadi didaerah pedesaan, mengakibatkan suatu keadaan yang timpang. Adapun ketimpangan yang dimaksud ialah timbulnya suatu istilah yang disebut dengan beban ganda yang diakibatkan oleh kemiskinan tadi. Beban ganda ini merupakan salah satu bentuk ketidakadilan dalam gender. Dimana pengertian beban ganda ialah beban pekerjaan yang diterima oleh salah satu jenis kelamin lebih banyak daripada jenis kelamin lainnya. Beban ganda seringkali menimbulkan kerentanan dan ketidakadilan bagi perempuan, terutama pada keluarga miskin dan mereka yang bekerja sebagai buruh.

Namun keputusan perempuan untuk bekerja tidak sejalan dengan kendala kemiskinan yang mereka hadapi, terutama budaya yang tidak berpihak kepada mereka. Artinya budaya yang ada dalam masyarakat tetap menginginkan perempuan untuk mengurus urusan domestic/rumah tangga walaupun sudah bekerja (urusan publik), tanpa adanya pembagian pekerjaan rumah dengan suami mereka. Sebab pada umumnya laki-laki enggan mengerjakan pekerjaan yang berhubungan dengan ranah domestik tidak masalah apabila ada pembagian pekerjaan rumah tangga yang baik yang harus ditanggung seorang perempuan antar anggota keluarga terutama suami. Tetapi kebanyakan laki-laki tidak mau mengerjakan pekerjaan yang berhubungan dengan ranah domestik. Sehingga timbulah beban ganda bagi ibu rumah tangga yang bekerja.

Penelitian tentang beban ganda telah banyak dilakukan oleh 
peneliti-peneliti terdahulu, antara lain Double Burden Istri Dan Pengaruhnya Terhadap Peran Suami Istri Dalam RumahTangga oleh Khasanah (2018). Penelitian ini memfokuskan pada pengaruh double burden istri bekerja yang mengakibatkan ketidakadilan peran di antara suami dan istri dalam kehidupan rumah tangga. Peran suami yang semula menjadi tulang punggung keluarga menjadi tergeser oleh istri yang bekerja.

Selanjutnya Dampak Peran Ganda Pekerja Perempuan Terhadap Keluarga Dan Kegiatan Sosial yang dilakukan oleh Nurjannah (2011). Penelitian ini memfokuskan kepada dampak peran ganda yang dialami oleh pekerja perempuan terhadap keluarga dan kegiatan sosial di masyarakatnya. Kemudian penelitian tentang Peran Ganda Perempuan Pemetik Teh. Penelitian ini dilakukan oleh Kusumawati (2012), yang tertuju pada penelitian tentang pembagian waktu perempuan pemetik teh sebagai efek dari beban ganda yang dialaminya. Dimana waktu perempuan pemetik teh untuk bekerja baik domestik maupun publik lebih banyak daripada suami mereka tetapi mendapatkan upah yang rendah dibandingkan suaminya.

\section{METODE PENELITIAN}

Jenis penelitian yang penulis gunakan ialah kualitatif dengan metode deskriptif. Bogdan dan Taylor (dalam Sujarweni, 2018:6), mendefenisikan bahwa penelitian kualitatif adalah satu prosedur penelitian yang menghasilkan data deskriptif berupa ucapan atau tulisan dan perilaku orang-orang yang diamati. Dikatakan penelitian kualitatif karena menuntut peneliti untuk memahami bagaimana kehidupan perempuan keluarga miskin yang menimbulkan beban ganda terhadap dirinya, yang didapatkan dengan cara interaksi dan komunikasi yang mendalam melalui wawancara, observasi, dan dokumentasi.

Penelitian ini dilakukan di Nagari Koto Baru Simalanggang khususnya pada peternakan ayam yang ada di sana. Alasan peneliti memilih penelitian di lokasi tersebut karena Nagari Koto Baru Simalanggang merupakan salah satu nagari yang memiliki lahan peternakan ayam yang cukup luas dan pekerjanya didominasi oleh perempuan (ibu rumah tangga). Hal tersebut membuat perempuan buruh mengalami beban ganda karena mereka harus bekerja di ruang publik dan juga di ruang domestic (rumah). Beban ganda yang dirasakan membuat masyarakat sering mengejek dan mencemooh. Selain itu 
pekerjaannya dianggap rendah dan juga para suami mereka menjadi malas-malasan untuk bekerja.

Penentuan informan dalam penelitian ini ialah menggunakan teknik purposive sampling. Purposive sampling (sampel bertujuan)merupakan teknik yang dimana sampel ditetapkan secara sengaja oleh peneliti, sehingga peneliti mendapatkan hasil yang beragam sesuai dengan yang diinginkan (Burhan Bungin, 2003;53-54). Data dikumpulkan melalui observasi dan wawancara mendalam (in depth interview), serta dokumentasi. Pada penelitian ini teknik pengabsahan data yang digunakan adalah triangulasi. Triangulasi menurut Moeleong (2009:330) adalah teknik pemeriksaan keabsahan data yang dimanfaatkan sesuatu yang lain dari luar data yang digunakan untuk keperluan pengecekan atau sebagai perbandingan terhadap data tersebut. Analisis data pada penelitian ini menggunakan teknik Miles dan Hurben (1984) dengan tahapan reduksi data, penyajian data, dan verfikasi data.

\section{HASIL DAN PEMBAHASAN}

Berdasarkan hasil
wawancara dan observasi yang
telah dilakukan, ditemukan alasan
yang melatarbelakangi perempuan
bekerja sebagai buruh peternakan
ayam. Pada dasarnya alasan yang mendorong perempuan bekerja sebagai buruh peternakan ayam adalah untuk pemenuhan kebutuhan ekonomi keluarga, sebab suami mereka sebagian besar hanya bekerja seadanya atau hanya terserap dalam sektor swasta yang berpenghasilan tidak menentu. Sehingga penghasilan suami tidak mampu mencukupi kebutuhan keluarga.

Bukan menjadi tugas utama bagi seorang perempuan atau ibu untuk bekerja atau mencari nafkah bagi keluarga. Akan tetapi dengan keadaan ekonomi keluarga yang masih kekurangan, akhirnya kondisi seperti inilah yang membuat perempuan atau ibu harus ikut bekerja. Dengan adanya peternakan ayam di Nagari Koto Baru Simalanggang, telah memberikan harapan bagi sebagian besar perempuan untuk bekerja. Dapat dikatakan bahwa para buruh perempuan menggantungkan hidupnya dari bekerja di peternakan ayam tersebut.

Terlebih pada umumnya perempuan buruh yang bekerja di peternakan ayam memiliki latar pendidikan yang rendah, sehingga mereka tidak memiliki keahlian khusus untuk mendapatkan pekerjaan yang lain. Sehingga menjadi buruh peternakan ayam menjadi pilihan perempuan buruh tersebut. Sesuai dengan pendapat 
Wijayanti (2010:84), perempuan buruh pada umumnya memiliki tingkat pendidikan rendah, bekerja disektor pekerjaan yang tidak memerlukan pendidikan tinggi, keterampilan dan keahlian khusus, serta berupah yang rendah.

Sebagai perempuan buruh peternakan ayam yang berstatus ibu rumah tangga yang bekerja, tidak dapat dipungkiri bahwa perempuan buruh adalah sosok ibu bagi anak-anak mereka, istri bagi suaminya, serta buruh atau pekerja yang harus mematuhi aturan yang ada di tempat kerja. Jadi dalam kehidupannya, perempuan buruh harus mengemban tugas-tugas domestik sekaligus tugas publik.

Adapun tugas domestik yang mereka kerjakan yaitu memasak, mencuci, mengurus keperluan suami dan anak, beberes, dan lain-lain. Sedangkan di tempat kerja perempuan buruh harus memberi makan dan minum ayam, mengontrol makan dan minum tersebut, memungut telur, membersihkan kandang ayam, dan lain-lain. Berikut gambar saat perempuan buruh bekerja di peternakan ayam.

Perempuan

buruh peternakan ayam yang berstatus ibu rumah tangga memiliki peran yang banyak atau peran ganda dalam kehidupannya. Semua hal tersebut tidak masalah kalau perempuan buruh senang menjalaninya dan adanya pembagian pekerjaan yang baik dalam keluarganya. Namun yang sering terjadi bahwa, tidak adanya pembagian pekerjaan yang jelas antara anggota keluarga yang menimbulkan keluhan capek, badan sakit-sakit dan lain sebagainya. Ditambah lagi pandangan yang kurang baik atau pembicaraan yang tidak pantas mereka terima dari masyarakat.

Hal di atas menunjukkan hal yang seharusnya tidak diterima oleh perempuan buruh, sebab semua pekerjaan tidak mungkin diemban kepada mereka semuanya. Karena perempuan buruh juga memiliki keterbatasan dan kekurangan yang pada gilirannya menimbulkan beban ganda dalam kehidupan perempuan buruh.

Sejalan dengan teori beban ganda yang dijelaskan oleh Hidayati (2015:109) bahwa beban ganda (double burden) ialah beban pekerjaan yang diterima salah satu jenis kelamin lebih banyak dibandingkan jenis kelamin lainnya.

Dari beban ganda yang dialami perempuan buruh di atas, timbul beberapa dampak dalam kehidupan mereka, yang meliputi dampak positif dan dampak negatif. Adapun dampak positif 
yang timbul akibat beban ganda yang dialami perempuan buruh peternakan ayam ialah sebagai berikut:

Menambah penghasilan rumah tangga

Tujuan dari perempuan buruh bekerja di peternakan ayam adalah untuk memperoleh gaji yang dapat digunakan untuk menambah penghasilan dalam rangka pemenuhan kebutuhan sehingga dapat meringankan beban suami. Adapun gaji yang diterima perempuan buruh tergantung pada jumlah ayam yang mereka kontrol. Rata-rata perempuan buruh yang bekerja di peternakan ayam mengontrol 5.000 ekor ayam. Perempuan buruh peternakan ayam menerima gaji Rp300.00 per 1.000 ekor ayam yang dikontrolnya. Jadi gaji yang mereka peroleh tergantung dari berapa banyak jumlah ayam yang mereka kontrol. Hal ini menunjukkan bahwa perempuan juga ikut berperan dalam menambah pendapatan keluarga untuk pemenuhan kebutuhan sehari-harinya. Walaupun sebenarnya yang berkewajiban penuh untuk memenuhi kebutuhan keluarga adalah suami mereka.

Meningkatkan kemitra-sejajaran antara istri dan suami dalam keluarga

Dengan bekerjanya ibu rumah tangga di luar rumah berarti mereka juga mampu berkecimpung dengan urusan publik. Seperti halnya suami mereka yang berperan sebagai pencari nafkah utama. Ini menunjukkan adanya kemitra-sejajaran antara perempuan dan laki-laki dalam rumah tangga. Perempuan tidak hanya berperan dalam urusan rumah tangga saja, tetapi juga dalam urusan mencari nafkah.

Sedangkan dampak negatif yang ditimbulkan ialah sebagai berikut:

Waktu untuk berkumpul dengan keluarga menjadi terbatas

Waktu berkumpul dengan keluarga merupakan hal yang sangat penting untuk membangun keharmonisan dalam keluarga. Namun, karena keadaan ekonomi perempuan buruh peternakan ayam yang mengharuskan mereka bekerja, membuat waktunya tersita di tempat bekerja. Sehingga untuk membangun sebuah keharmonisan dalam keluarga menjadi cukup sulit. Apalagi bagi mereka yang sama-sama sibuk bekerja. Mereka hanya dapat bertemu di waktu pagi hari sebelum berangkat kerja dan malam hari menjelang tidur malam.

Adanya beban kerja ganda yang harus ditanggung perempuan buruh peternakan ayam

Banyaknya tanggung jawab yang harus dijalankan oleh perempuan yang sudah berkeluarga membuat mereka memiliki beban kerja 
ganda. Hal ini yang dirasakan oleh perempuan yang bekerja pada peternakan ayam di Nagari Koto Baru Simalanggang. Perempuan buruh harus mengurus rumah sekaligus mengurus urusan di luar rumah (tempat bekerja). Pekerjaan rumah yang seharusnya ada pembagian yang baik antar anggota keluarga terutama suami perempuan buruh, tidak terwujud. Sebab kebanyakan laki-laki atau suami enggan melakukan pekerjaan yang berhubungan dengan ranah domestik.

Timbulnya cemoohan dan pandangan yang tidak menyenangkan dari masyarakat

Dengan bekerja perempuan buruh di peternakan ayam menimbulkan hal yang tidak menyenangkan bagi dirinya. Yaitu cemoohan atas pekerjaan yang mereka lakukan serta pandangan yang tidak menyenangkan. Mulai dari cemoohan terhadap pekerjaan yang dilakoni, pembicaraan yang tidak enak didengar mengenai dirinya, dan hal lain yang membuat perempuan buruh peternakan ayam semakin merasakan beban akibat dari keadaan kehidupannya sebagai perempuan pekerja.

Untuk menghadapi beban ganda yang dialami perempuan buruh peternakan ayam, maka mereka harus mampu mengatur waktu dengan baik. Manajemen waktu yang dilakukan adalah dengan memanfaatkan waktu luang untuk keluarga dan istirahat. Manajemen waktu yang baik juga merupakan upaya yang pekerja perempuan lakukan untuk mengatasi dampak beban ganda. Selain itu perempuan buruh harus mampu memotivasi diri sendiri agar mereka tetap bersemangat untuk bekerja yaitu dengan mengingat banyaknya kebutuhan yang harus mereka penuhi

\section{KESIMPULAN}

Beban ganda yang dialami perempuan buruh keluarga miskin pada peternakan ayam dilatarbelakangi oleh keadaan ekonomi keluarga yang lemah. Sebab suami mereka sebagai pencari nafkah utama pada umumnya hanya bekerja seadanya atau serabutan sehingga penghasilan yang diperoleh tidak mencukupi kebutuhan keluarga. Kondisi ini membuat perempuan buruh memutuskan untuk bekerja demi menambah penghasilan keluarga sekaligus membantu suami mencari nafkah. Dengan bekerjanya para perempuan buruh membuat mereka harus menjalankan peran yang ganda.

Tidaklah mudah mengerjakan dua peran pekerjaan sekaligus. Apalagi pekerjaan mereka sebagai buruh yang dapat dikatakan cukup berat bagi seorang 
perempuan. Belum lagi pekerjaan rumah yang juga banyak serta tidak adanya pembagian pekerjaan yang jelas dalam keluarga para perempuan buruh. Selain itu cemoohan dan pandangan yang tidak menyenangkan dari masyarakat kerap mereka terima yang menimbulkan beban ganda dalam kehidupan perempuan buruh.

Beban ganda yang dialami perempuan buruh peternakan ayam memberikan dampak positif dan negatif. Dampak positif yang ditimbulkan dari beban ganda perempuan buruh peternakan ayam yaitu menambah penghasilan rumah tangga, meningkatkan kemitrasejajaran antara suami dan istri dalam keluarga. Sedangkan dampak negatif yang ditimbulkan dari beban ganda perempuan buruh ialah waktu berkumpul dengan keluarga manjadi terbatas, beban pekerjaan yang banyak yang diemban oleh perempuan buruh, lalu cemoohan dan pandangan yang kurang baik dari masyarakat kerap mereka terima. Untuk menghadapi beban ganda yang dialami perempuan buruh, maka strategi yang dapat mereka lakukan diantaranya yaitu, memanajemen waktu dengan baik, serta memotivasi diri sendiri untuk mengantisipasi masalah yang timbul agar tetap semangat bekerja.

\section{DAFTAR PUSTAKA}

Hidayati, Nurul. 20115. Beban Ganda Perempuan Bekerja (Antara Domestik dan Publik. Jurnal Muwazah. Volume 7. Nomor 2. Hal 108.

Huraerah, Abu. 2013. Srategi

Kebijakan

Penanggulangan

Kemiskinan di Indonesia. Jurnal Ilmu Kesejahteraan Sosial.

Volume 12. Nomor 1. Hal 3.

J, Lexy Moleong. 2012. Metode Penelitian Kualitatif. PT Remaja Rosdakarya Offset : Bandung.

Jacobus, Elvira Handayani. 2018. Analisis Faktor-Faktor Yang Mempengaruhi Kemiskinan Rumah Tangga Di Sulawesi Utara. Jurnal Pembangunan Ekonomi Dan Keuangan Daerah. Volume 19.Nomor 7.Hal 5.

Noerdin, Edriana dkk. 2006. $\begin{array}{lr}\text { Potret } & \text { Kemiskinan } \\ \text { Perempuan. } & \text { Women }\end{array}$ 
Research Institute: Www.badan-pusat-

Jakarta. statistik.go.id.

Santi, Sarah. 2007. Perempuan

Dan Kemiskinan:

Pembangunan,

Kebijakan, Dan

Feminisasi Kemiskinan.

Jurnal Forum Ilmiah

Indonusa. Volume 4.

Nomor 1. Hal 1.

Sugiyono.2017. Metode Penelitian

Kuantitatif, Kualitatif

dan RED. Bandung:

Alfabeta.

Suhartini, Sri. 2010. Pergulatan

Hidup Perempuan

Pemecah Batu. Jurnal

Komunitas. Volume 2.

Nomor 2. Hal 107.

Sujarweni, Wiratna. 2018.

Metodologi Penelitian.

Pustaka Baru Press:

Yogyakarta.

Sukesi, Keppi. 2015. Gender Dan

Kemiskinan.

Universitas Brawijaya

Press : Malang.

Wijayanti. 2010. Belenggu

Kemiskinan Buruh

Perempuan Pabrik

Rokok. Jurnal Komunitas.

Volume 3. Nomor 2. Hal

86. 